\title{
Roles of prostaglandin F2alpha and hydrogen peroxide in the regulation of Copper/Zinc superoxide dismutase in bovine corpus luteum and luteal endothelial cells
}

\author{
Hai V Vu, Tomas J Acosta*, Shin Yoshioka, Hironori Abe and Kiyoshi Okuda
}

\begin{abstract}
Background: Prostaglandin F2alpha (PGF) induces luteolysis in cow by inducing a rapid reduction in progesterone production (functional luteolysis) followed by tissue degeneration (structural luteolysis). However the mechanisms of action of PGF remain unclear. Reactive oxygen species (ROS) play important roles in regulating the luteolytic action of PGF. The local concentration of ROS is controlled by superoxide dismutase (SOD), the main enzyme involved in the control of intraluteal ROS. Thus SOD seems to be involved in luteolysis process induced by PGF in cow.

Methods: To determine the dynamic relationship between PGF and ROS in bovine corpus luteum (CL) during luteolysis, we determined the time-dependent change of Copper/Zinc SOD (SOD1) in CL tissues after PGF treatment in vivo. We also investigated whether PGF and hydrogen peroxide (H2O2) modulates SOD1 expression and SOD activity in cultured bovine luteal endothelial cells (LECS) in vitro.

Results: Following administration of a luteolytic dose of PGF analogue $(0 \mathrm{~h})$ to cows at the mid-luteal stage, the expression of SOD1 mRNA and protein, and total SOD activity in CL tissues increased between 0.5 and $2 \mathrm{~h}$, but fell below the initial $(0 \mathrm{~h})$ level at $24 \mathrm{~h}$ post-treatment. In cultured LECS, the expression of SOD1 mRNA was stimulated by PGF (1-10 microM) and H2O2 (10-100 microM) at $2 \mathrm{~h}(\mathrm{P}<0.05)$. PGF and $\mathrm{H} 2 \mathrm{O} 2$ increased SOD1 protein expression and total SOD activity at $2 \mathrm{~h}(\mathrm{P}<0.05)$, whereas PGF and $\mathrm{H} 2 \mathrm{O} 2$ inhibited SOD1 protein expressions and total SOD activity at $24 \mathrm{~h}(\mathrm{P}<0.05)$. In addition, $\mathrm{H} 2 \mathrm{O} 2$ stimulated PGF biosynthesis at 2 and $24 \mathrm{~h}$ in bovine LECs. Overall results indicate that, SOD is regulated by PGF and ROS in bovine LECs. SOD may play a role in controlling intraluteal PGF and ROS action during functional and structural luteolysis in cows.
\end{abstract}

Keywords: Bovine, Corpus luteum, Prostaglandin $\mathrm{F}_{2 a}$, Hydrogen peroxide, Superoxide dismutase, Luteal endothelial cell

\section{Background}

Prostaglandin $\mathrm{F}_{2 \alpha}$ (PGF) from the uterus or from the ovary is responsible for the regression of the corpus luteum (CL) in mammals [1,2]. In vivo studies in cows demonstrated that intramuscular injections of PGF analogues given in the mid-luteal stage induce an acute decrease in progesterone $\left(\mathrm{P}_{4}\right)$ production (functional luteolysis) followed by tissue degradation and a decrease in size of the CL (structural

\footnotetext{
* Correspondence: acosta@cc.okayama-u.ac.jp

Laboratory of Reproductive Physiology, Graduate School of Natural Science and Technology, Okayama University, Okayama 700-8530, Japan
}

luteolysis) [2]. On the other hand, in vitro studies showed that direct treatment of pure populations of luteal steroidogenic cells (LSCs) with PGF does not inhibit basal $\mathrm{P}_{4}$ production by the large LSCs, and stimulates $\mathrm{P}_{4}$ production by the small LSCs and by a mixture of large and small LSCs $[3,4]$ suggesting that PGF action differs in each type of luteal cells. The exact mechanism involved in the luteolytic cascade initiated by PGF remains unclear. Interestingly, several studies reported the presence of PGF receptors in luteal endothelial cells (LECs) and that LECs respond to PGF stimulation [5,6], suggesting that LECs are a target for

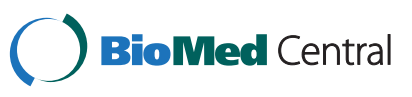


PGF, and that LECs play roles in the local mechanism of $\mathrm{CL}$ regression induced by PGF.

Reactive oxygen species (ROS) including hydrogen peroxide $\left(\mathrm{H}_{2} \mathrm{O}_{2}\right)$, superoxide anion $\left(\mathrm{O}_{2}^{-}\right)$and hydroxyl radical $\left(\mathrm{OH}^{-}\right)$have been implicated in the luteolytic process [7]. In rats, PGF induces a decrease in serum concentrations of $\mathrm{P}_{4}$ in association with increasing generation of superoxide anion and $\mathrm{H}_{2} \mathrm{O}_{2}$ in the luteal tissue [8]. Treatment of LSCs with PGF induces ROS production and apoptosis [9]. Moreover, $\mathrm{H}_{2} \mathrm{O}_{2}$ was found to stimulate PGF production in human endometrial stromal cells [10]. We recently observed that an injection of PGF induces a transient $(1-2 \mathrm{~h})$ increase in the partial pressure of oxygen $\left(\mathrm{pO}_{2}\right)$ in ovarian venous blood [11], and that the $\mathrm{pO}_{2}$ of venous blood is higher in the ovarian vein than in the jugular vein in cow. Therefore, the luteal microenvironment seems to be exposed to high $\mathrm{O}_{2}$ condition, especially during the short period of time (1-2 h) following PGF treatment.

Superoxide dismutase (SOD) acts as an antioxidant enzyme in nearly all cells exposed to oxygen. SOD catalyzes the dismutation of superoxide into oxygen and $\mathrm{H}_{2} \mathrm{O}_{2}$. Mammalian cells have three forms of SOD. Copper/Zinc (SOD1) is present in the cytosol, nucleus and the intermembrane space of mitochondria; Manganese SOD (SOD2) is a manganese-containing enzyme that is present in the mitochondrial matrix; Extracellular SOD (SOD3) is a secreted copper-containing protein that is found in the extracellular matrix of tissues [12]. SOD1 dismutates superoxide radicals resulting from cellular oxidative metabolism into $\mathrm{H}_{2} \mathrm{O}_{2}$ [13] represents $80 \%$ of the total SOD found in the rat CL [14]. In addition, a decrease in intracellular SOD activity was accompanied by a decrease of $\mathrm{P}_{4}$ production by rat CL [15]. However, the local mechanisms controlling the luteolytic actions of PGF in LECs remain unknown. We hypothesized that SOD, the main enzyme involved in the control of intraluteal ROS, is differently regulated at the time of functional $(2 \mathrm{~h})$ and structural $(24 \mathrm{~h})$ luteolysis.

To test the above hypothesis, we determined the timedependent changes of SOD in CL tissues after PGF treatment in vivo and the influence of PGF and $\mathrm{H} 2 \mathrm{O} 2$ on SOD1 expression and SOD activity in bovine LECs in vitro.

\section{Methods}

\section{Collection of $\mathrm{CL}$ tissue during PGF-induced luteolysis}

The animal procedures were approved by the local institutional animal care and use committee of Polish Academy of Sciences in Olsztyn, Poland (Agreement No. 5/2007, 6/2007 and 88/2007). Healthy normally cycling Polish Holstein Black and White cows were used for collection of CL. Estrus was synchronized in the cows by two injections of an analogue PGF (Dinoprost, Dinolytic; Pharmacia \& Upjohn, Belgium) with an 11-days interval. Ovulation was determined by a veterinarian via transrectal ultrasonography examination. Then, CLs were collected by Colpotomy technique using a Hauptner's effeninator (Hauptner and Herberholz, Solingen, Germany) on day 10 post-ovulation, i.e., just before administration of a luteolytic dose of analogue PGF (Dinoprost, Dinolytic; Pharmacia \& Upjohn, Belgium) (0 h), and at $0.5,2,12$ and $24 \mathrm{~h}$ post-treatment $(\mathrm{n}=4$ per timepoint). CL tissues were dissected from the ovary and then stored at $-80^{\circ} \mathrm{C}$ until the $S O D 1 \mathrm{mRNA}$, protein and total SOD activity analysis.

\section{Bovine LEC isolation and cell culture}

LECs were isolated from five CLs at the mid-luteal phase (days 8-12 of the estrous cycle) [16] using magnetic beads as previously described [17] and recently validated in our laboratory [6,18]. Briefly, magnetic tosylactivated beads (Dynabeads M-450, 140.04; Dynal ASA, Oslo, Norway) were coated with $0.15 \mathrm{mg} / \mathrm{ml}$ lectin from Bandeiraea simplicifolia (BS-1; L2380; Sigma-Aldrich, St. Louis, MO, USA), which specifically binds the glycoproteins expressed by bovine LECs [17]. Luteal cell (LC) suspension was mixed with beads at a concentration of $4 \times 10^{8}$ beads $/ \mathrm{ml}$, and incubated for $20 \mathrm{~min}$ at $4^{\circ} \mathrm{C}$ on a rocking platform. The cells were pooled and cultured in endothelial cell (EC) growth medium (MV 2; C22121; Promo Cell, Heidelberg, Germany) at $37^{\circ} \mathrm{C}$ in a humidified atmosphere of $5 \% \mathrm{CO}_{2}$ in air. Only colonies with a homogeneous cell population were removed with a pipette and cultured in collagen-coated $25 \mathrm{~cm}^{2}$ culture flasks (690175; Greiner Bio-One, Frickenhausen, Germany). The cultures and passages were repeated until a homogeneous population of pure LECs was obtained. The LECs used in the present study were previously confirmed to be positively stained with rabbit anti-human von Willebrand factor (vWF, F3520; Sigma-Aldrich), isolated LECs expresses CD31 but not $3 \beta$-hydroxysteroid dehydrogenase $(3 \beta-H S D)$ mRNA as reported previously $[6,17,18]$. Experiments were performed on confluent cultures and the cells (LECs) were from passage 2-5.

The LECs were seeded at a concentration of $1 \times 10^{5}$ viable cells $/ \mathrm{ml}$ into 24-well plates (662160; Greiner Bio-One) for determination of SOD1 mRNA or PGF production, and $1 \times 10^{6}$ viable cells $/ \mathrm{ml}$ into $75-\mathrm{cm}^{2}$ culture flasks (658175; Greiner Bio-One) for determination of SOD1 protein expression and total SOD activity in culture cells. LECs were cultured in DMEM/F-12 (D/F; D8900; Sigma-Aldrich) supplemented with $10 \%$ calf serum (v/v, 16170-078; Life Technologies Inc., Grand Island, NY, USA), $20 \mu \mathrm{M}$ gentamicin (G1397; Sigma-Aldrich) and 2 $\mu \mathrm{M}$ amphotericin B (A9528; Sigma-Aldrich). The cells reached confluence on $5^{\text {th }}$ day of culture. After the cells reached confluence, the medium was replaced with fresh $\mathrm{D} / \mathrm{F}$ supplemented with $5 \mu \mathrm{g} / \mathrm{ml}$ holo-transferrin (T3400; Sigma-Aldrich), $500 \mu \mathrm{M}$ ascorbic acid (013-12061; Wako 
Pure Chemical Industries, Ltd., Osaka, Japan), $5 \mathrm{nM}$ sodium selenite (S5261; Sigma-Aldrich), and 0.1\% (w/v) BSA (10 735078 001; Roche Diagnostics, Mannheim, Germany).

\section{Cell viability test}

LECs cultured in 96-well plates were exposed to $\mathrm{H}_{2} \mathrm{O}_{2}(0.1$ $-1000 \mu \mathrm{M}$ ) for the final $24 \mathrm{~h}$ of culture. The cell viability was determined by Dojindo Cell Counting Kit including WST-1 (Dojindo, Kumamoto, Japan; No. 345-06463). Briefly, WST-1, a kind of MTT [3-(4,5-dimethyl-2 thiazolyl)-2,5-diphenyl-2 H-tetrazolium bromide], is a yellow tetrazolium salt that is reduced to formazan by live cells containing active mitochondria. The culture medium was replaced with $100 \mu \mathrm{l}$ /F without phenol red medium-BSA, and a 10- $\mu \mathrm{l}$ aliquot (0.3\% WST-1, $0.2 \mathrm{mM}$ 1-methoxy PMS in PBS, $\mathrm{pH}$ 7.4) was added to each well. The cells were then incubated for $4 \mathrm{~h}$ at $38^{\circ} \mathrm{C}$. The absorbance (A) was read at $450 \mathrm{~nm}$ using a microplate reader (Bio-Rad, Hercules, CA; Model 450). Percentage of cytotoxicity was determined by subtracting the mean A of $\mathrm{H}_{2} \mathrm{O}_{2}$-treated wells $\left(\mathrm{A}_{\text {test }}\right)$ from the mean $\mathrm{A}$ of untreated wells $\left(\mathrm{A}_{\text {control }}\right)$ and then dividing by the mean $A$ of untreated wells $\left(\mathrm{A}_{\text {control }}\right)$. The mean $\mathrm{A}$ of wells in the absence of the cells was subtracted from the mean A of all experimental wells. The percent cytotoxicity was calculated as $100 \times\left(\mathrm{A}_{\text {control }}-\mathrm{A}_{\text {test }}\right) /\left(\mathrm{A}_{\text {control }}\right)$.

\section{Dose-dependent effect of PGF and $\mathrm{H}_{2} \mathrm{O}_{2}$ on SOD1 mRNA expression at $2 \mathrm{~h}$ in vitro}

To determine whether LECs were responsive to increased concentrations of PGF and $\mathrm{H}_{2} \mathrm{O}_{2}$ in the present culture system, LECs cultured in 24-well plates were incubated for $2 \mathrm{~h}$ with or without 0.1-10 $\mu \mathrm{M}$ PGF or 1-100 $\mu \mathrm{M} \mathrm{H}_{2} \mathrm{O}_{2}$ ( $\mathrm{n}=4$ experiments). The cells were then collected and stored at $-80^{\circ} \mathrm{C}$ for the analysis of SOD1 mRNA expression.

\section{SOD1 protein and total SOD activity at $2 \mathrm{~h}$ and at $24 \mathrm{~h}$ in vitro}

To examine whether SOD is differently regulated by PGF and $\mathrm{H}_{2} \mathrm{O}_{2}$ at the time of functional and structural luteolysis, LECs cultured in $75-\mathrm{cm}^{2}$ culture flasks were incubated for $2 \mathrm{~h}$ (mimicking functional luteolysis) and $24 \mathrm{~h}$ (mimicking structural luteolysis) with or without PGF $(1 \mu \mathrm{M})$ or $\mathrm{H}_{2} \mathrm{O}_{2}(10 \mu \mathrm{M})$. The samples were then used for analysis of SOD1 protein expression and total SOD activity $(\mathrm{n}=4$ experiments). The concentrations of PGF and $\mathrm{H}_{2} \mathrm{O}_{2}$ were chosen based on the result of SOD1 mRNA expression in vitro, and the effect of $\mathrm{H}_{2} \mathrm{O}_{2}$ on cell viability

\section{PGF production in vitro}

To determine the dose-dependent effects of $\mathrm{H}_{2} \mathrm{O}_{2}$ on PGF production, LECs cultured in 24-well plates were exposed to $\mathrm{H}_{2} \mathrm{O}_{2}(1-100 \mu \mathrm{M})$ for $2 \mathrm{~h}$ or $24 \mathrm{~h}$. After incubation, the conditioned media were collected in $1.5 \mathrm{ml}$ tubes containing $5 \mu \mathrm{l}$ of a stabilizer solution (0.3 M EDTA, 1\% (w/v) acid acetyl salicylic, $\mathrm{pH}$ 7.3) and frozen at $-30^{\circ} \mathrm{C}$ until the PGF assay ( $\mathrm{n}=4$ experiments).

\section{Reverse transcript-PCR}

Total RNA was prepared from the CL tissue or cultured bovine LECs using TRI reagent according to the manufacturer's direction (TRI Reagent RNA isolation protocol, () 2008 Ambion, Inc). One microgram of total RNA of each sample was reverse transcribed using a SuperScript First-Strand Synthesis System for RT-PCR (11904-018; Invitrogen), and the reaction mixture was used in each PCR together with the appropriate oligonucleotide primer pairs. The primer for SOD and beta-actin (ACTB) were designed and characterized as described previously [19]. Primer for SOD1 was: forward: AAGGCCGTCTGCGTGCTGAA; reverse: CAGGTCTCCAACATGCCTCT (accession No: M81129; product: $240 \mathrm{bp}$ ). Primer for ACTB was: Forward: CGGCATTCACGAAACTACC; Reverse: ATCAAGTCCTCGGCCACAC (accession No: AY141970; product: 536).

The RT-PCRs were conducted with the house-keeping gene ACTB as an internal standard. ACTB primer was added at the appropriate cycle number by the "primmerdropping method" as described by Wong et al. [20] with modification [21]. The PCRs were carried out using TaKaRa Taq (R001A; Takara Bio Inc., Shiga, Japan) and a thermal cycler (iCycler; Bio-rad Laboratories, Hercules, CA, USA). The PCR conditions were as follow: activation of DNA polymerase for $20 \mathrm{sec}$ at $95^{\circ} \mathrm{C}$, annealing for $1 \mathrm{~min}$ at $60^{\circ} \mathrm{C}$, and extension for $1 \mathrm{~min}$ at $70^{\circ} \mathrm{C}$, follow by final extension for $5 \mathrm{~min}$ at $72^{\circ} \mathrm{C}$. The number of cycles was 27 for SOD and 23 for ACTB. Two-fifths aliquot of each reaction mixture was electrophoresed on a $1.5 \%$ agarose gel containing ethidium bromide with a known standard (100-bp ladder, New England Biolabs Inc., Beverely, MA, USA; \#N3231S) and photographed under ultraviolet illumination. The integrated density was determined by Image software (Windows version of NIH Image, http://rsb.info. nih.gov/nih-image/, National Institutes of Health). Relative density was quantified by normalization of the integrated density of each corresponding $\beta$-actin.

\section{SOD1 protein expression}

SOD1 protein expression in luteal tissue and in cultured bovine LECs was assessed by Western immunoblotting analysis. Tissues or cells were lysed in $150 \mu \mathrm{l}$ lysis buffer (20 mM Tris-HCl, $150 \mathrm{mM} \mathrm{NaCl}, 1 \%$ Triton X-100 [BioRad Laboratories], 10\% glycerol [G7757; Sigma-Aldrich], Complete [11 697498 001; Roche Diagnostics, Basel, Switzerland], $\mathrm{pH}$ 7.4). Protein concentrations in the lysates were determined by the method of Osnes et al. [22], using BSA as a standard. The proteins were then 
solubilized in SDS gel-loading buffer (10\% glycerol, 1\% $\beta$-mercaptoethanol [137-06862; Wako Pure Chemical Industries, Ltd.], $\mathrm{pH}$ 6.8) and heated at $95^{\circ} \mathrm{C}$ for $10 \mathrm{~min}$. Samples $(50 \mu \mathrm{g}$ protein) were electrophoresed on a $15 \%$ SDS-PAGE for $1.5 \mathrm{~h}$ at $30 \mathrm{~mA}$. The separated proteins were electrophoretically transblotted to a $0.2-\mu \mathrm{M}$ nitrocellulose membrane (LC2000; Invitrogen) at $300 \mathrm{~mA} \mathrm{~V}$ for $3 \mathrm{~h}$ in transfer buffer $(25 \mathrm{mM}$ Tris- $\mathrm{HCl}$, $192 \mathrm{mM}$ glycine, $20 \%$ methanol, $\mathrm{pH}$ 8.3). The membrane was washed in TBS-T $(0.1 \%$ Tween 20 in TBS $[25 \mathrm{mM}$ Tris- $\mathrm{HCl}, 137 \mathrm{mM} \mathrm{NaCl}, \mathrm{pH} 7.5]$ ), incubated in blocking buffer (5\% nonfat dry milk in TBS-T) for $1 \mathrm{~h}$ at room temperature, incubated at $4^{\circ} \mathrm{C}$ with a primary antibody specific to each protein (goat SOD1 polyclonal antibody [23 kDa; 1:500 in TBS-T, overnight; sc-8637; Santa Cruz Biotechnology, Santa Cruz, CA, USA] and mouse ACTB monoclonal antibody [internal standard, $42 \mathrm{kDa}$; 1:4000 in TBS-T, overnight; A2228; Sigma-Aldrich]). The membrane was washed three times for $5 \mathrm{~min}$ in TBS-T at room temperature, incubated with secondary antibody (SOD1 [1:10000 in TBS-T]: anti-goat Ig, HRP-linked whole antibody produced in donkey, sc-2020; Santa Cruz; ACTB [1:40000 in TBS-T]: anti-mouse Ig, HRP-linked whole antibody produced in sheep, NA931; Amersham Biosciences, Buckinghamshire, UK) for $1 \mathrm{~h}$, and washed three times in TBS for $5 \mathrm{~min}$ at room temperature. The signal was detected by a ECL Western immunoblotting detection system (RPN2109; Amersham Biosciences). The intensity of the immunological reaction was estimated by measuring the optical density in the defined area by computerized densitometry using NIH Image (National Institutes of Health; Bethesda, MD, USA).

\section{Total SOD activity assay}

Total SOD activity was determined in CL tissues collected at $0,0.5,2,12$, and $24 \mathrm{~h}$ after PGF injection and in the LECs at the end of a 2-h or 24-h incubation period using SOD Assay Kit-WST (S311-08; Dojindo Laboratories, Kumamoto, Japan). Total SOD activity was calculated using a concurrently run SOD standard curve, and expressed as inhibition rate or percentage of control (raw data on total SOD activity was normalized based on protein concentrations, units per mg of cellular protein).

\section{Determination of PGF concentration}

The concentration of PGF in the culture medium was determined by enzyme immunoassay (EIA) as described previously [18]. The PGF standard curve ranged from 15.625 to $4000 \mathrm{pg} / \mathrm{ml}$, and the median effective dose $\left(E D_{50}\right)$ of the assay was $250 \mathrm{pg} / \mathrm{ml}$. The intra- and inter-assay coefficients of variation were 7.4 and $11.6 \%$, respectively. The cross-reactivities of the antibody were $100 \%$ for PGF, 3.0\% for PGD2, 1.1\% for PGI, $0.15 \%$ for PGE2, and $<0.03 \%$ for PGA2. The DNA content, estimated using the spectrophotometric method by Labarca \& Paigen [23], was used to standardize the PGF concentrations.

\section{Statistical analysis}

Data of SOD1 mRNA, protein level and total SOD activity were obtained in four separate experiments. PGF

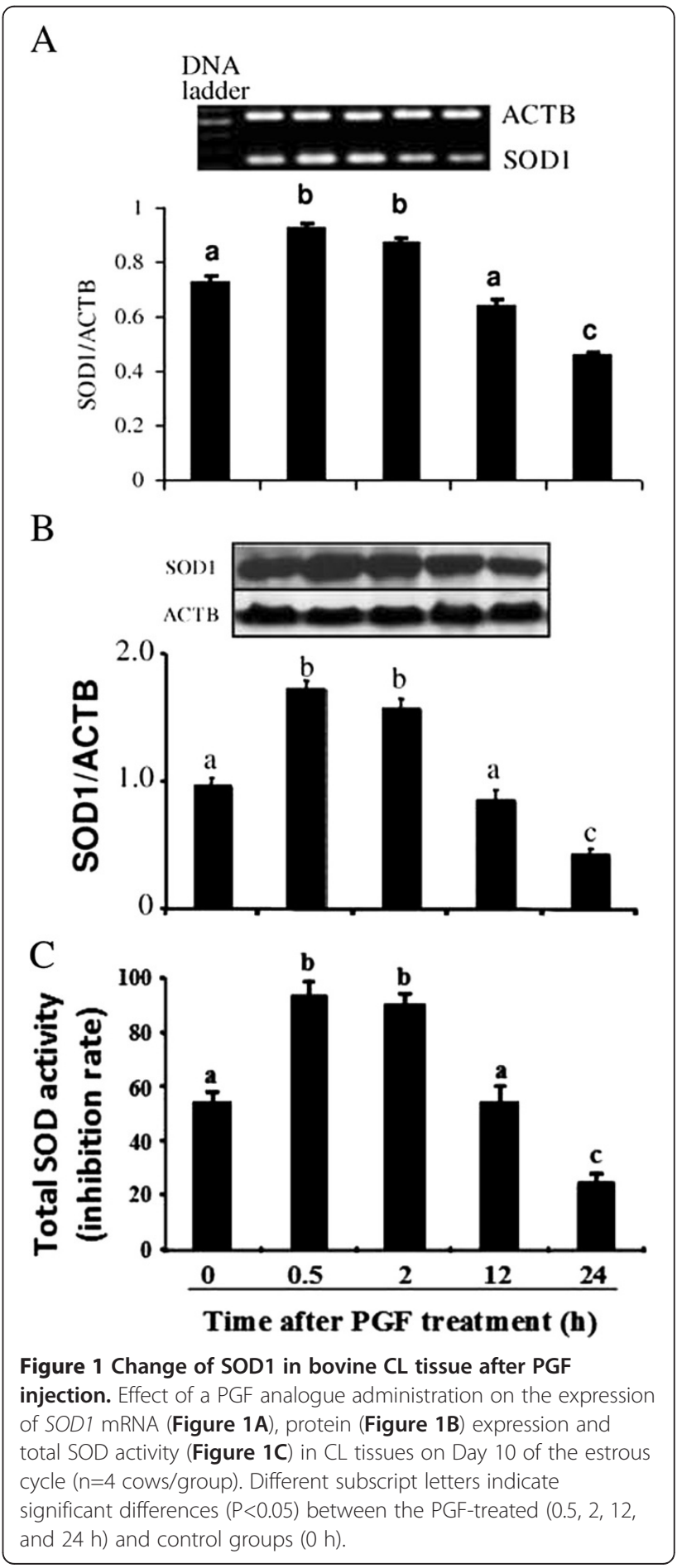




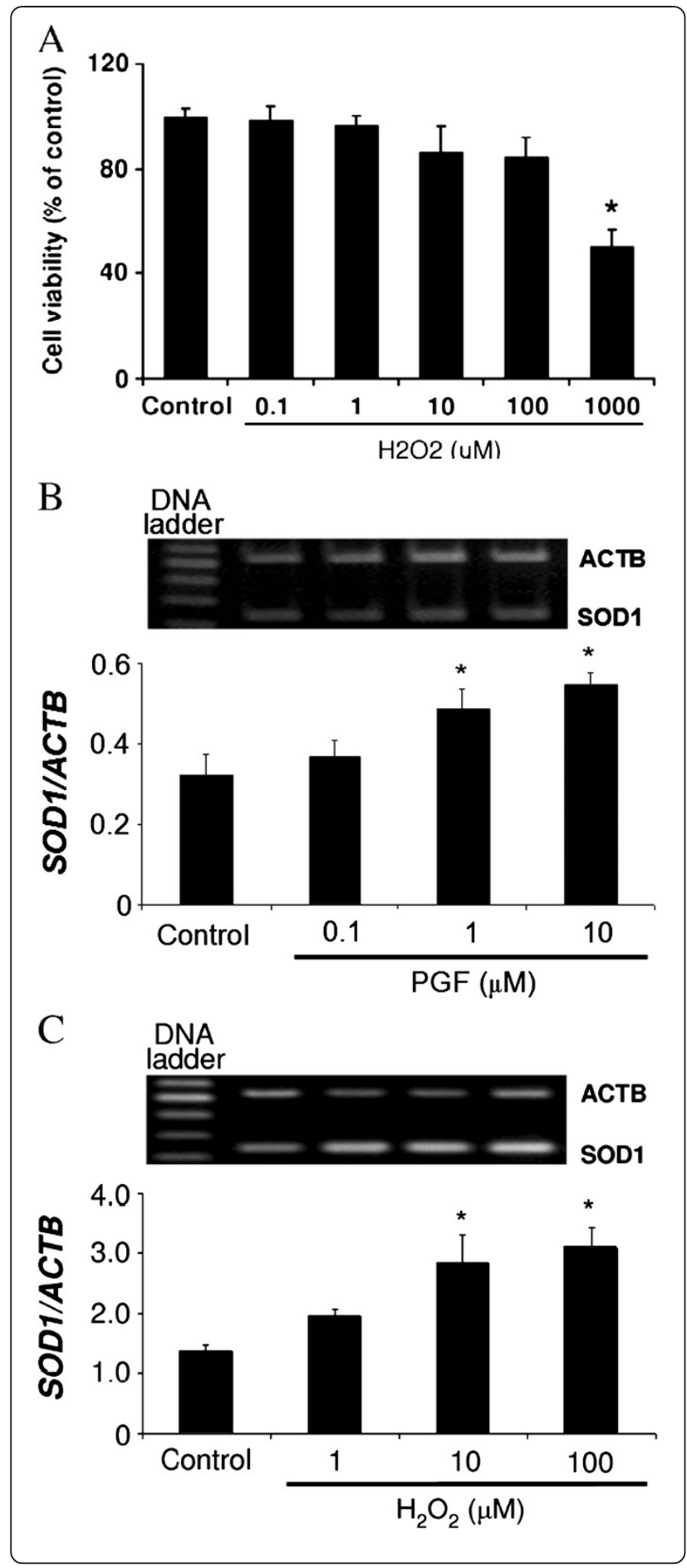

concentration and cell viability were performed in triplicate samples for each experimental group of LECs or CL tissues (in vivo). The statistical significances of differences in the amounts of SOD1 mRNA, protein levels, total SOD activity, cell viability and differences in PGF concentrations were analyzed using two-way analysis of variance (ANOVA) with repeated-measures or one-way ANOVA followed by
Figure 2 Cell viability test and SOD1 mRNA expression in LECs. Dose-dependent effects of $\mathrm{H}_{2} \mathrm{O}_{2}$ on the cell viability and dosedependent effects of PGF and $\mathrm{H}_{2} \mathrm{O}_{2}$ on SOD1 mRNA expression in cultured bovine LECS. The cells were cultured with $\mathrm{H}_{2} \mathrm{O}_{2}(1,10,100$ and $1000 \mu \mathrm{M}$ ) (Figure $2 \mathrm{~A}$ ) for $24 \mathrm{~h}$ for testing cell viability and with PGF $(0.1,1$ and $10 \mu \mathrm{M})$ (Figure 2B) and $\mathrm{H}_{2} \mathrm{O}_{2}(1-100 \mu \mathrm{M})$ (Figure 2C) for $2 \mathrm{~h}$ to evaluate of SOD1 mRNA expression change. Photographs showed the expression of SOD1 (240 bp) and ACTB (536 bp) mRNA. The amount of SOD1 mRNA is expressed relative to the amount of ACTB mRNA. Asterisks indicate significant differences between treated and untreated cells $(P<0.05)$. All values represent mean \pm SEM of four separate experiments.

Fisher's protected least-significant difference (PLSD) procedure as multiple comparison tests. All values were expressed as the mean \pm SEM of four separate experiments. A level of $P<0.05$ was considered to be statistically significant.

\section{Results}

SOD1 mRNA, protein expression and total SOD activity during PGF-induced luteolysis in vivo

Injection of a luteolytic dose of PGF increased the expression of SOD1 mRNA (Figure 1A), SOD1 protein (Figure $1 \mathrm{~B}$ ) and total SOD activity (Figure $1 \mathrm{C}$ ) from 0.5 to $2 \mathrm{~h}$ in bovine $\mathrm{CL}$ tissues, but decreased at $24 \mathrm{~h}$ $(\mathrm{P}<0.05)$.

Dose-dependent effects of $\mathrm{H}_{2} \mathrm{O}_{2}$ on LECs viability $\mathrm{H}_{2} \mathrm{O}_{2}$ at the concentrations from 1-100 $\mu \mathrm{M}$ did not cause significantly cell dead compared with control. However, $\mathrm{H}_{2} \mathrm{O}_{2}$ at $1000 \mu \mathrm{M}$ reduced significantly viability of LECs (Figure 2A).

Dose-dependent effect of PGF and $\mathrm{H}_{2} \mathrm{O}_{2}$ on SOD1 mRNA expression at $\mathbf{2} \mathrm{h}$ in vitro

Both PGF (1-10 $\mu \mathrm{M}$; Figure 2B) and $\mathrm{H}_{2} \mathrm{O}_{2}(10-100 \mu \mathrm{M}$; Figure 2C) induced mRNA expression of SOD1 in cultured bovine LECs incubated for $2 \mathrm{~h}(\mathrm{P}<0.05)$. However the lower doses of PGF $(0.1 \mu \mathrm{M})$ and $\mathrm{H}_{2} \mathrm{O}_{2}(1 \mu \mathrm{M})$ did not affect significantly SOD1 mRNA expression.

SOD1 protein and total SOD activity at $2 \mathrm{~h}$ and at $24 \mathrm{~h}$ in vitro

PGF and $\mathrm{H}_{2} \mathrm{O}_{2}$ significantly stimulated SOD1 protein expression (Figure 3A) and total SOD activity (Figure 3B) at $2 \mathrm{~h}(\mathrm{P}<0.05)$ in cultured LECs. However, PGF and $\mathrm{H}_{2} \mathrm{O}_{2}$ decreased SOD1 protein expression (Figure 3C) and total SOD activity (Figure 3D) at $24 \mathrm{~h}(\mathrm{P}<0.05)$ in cultured LECs.

\section{PGF production in vitro}

In cultured LECs, PGF production was simulated by $100 \mu \mathrm{M} \mathrm{H} \mathrm{O}_{2}$, but not by lower concentrations at $2 \mathrm{~h}$ (Figure 4A) and 24 h (Figure 4B) $(\mathrm{P}<0.05)$. 


\section{Discussion}

The present study demonstrated that administration of a luteolytic dose of PGF increased the expression of SOD1 in the $\mathrm{CL}$ tissue between 0.5 and $2 \mathrm{~h}$ post-treatment, but decreased at $24 \mathrm{~h}$ in vivo. Furthermore, in vitro studies examining the effects of PGF and $\mathrm{H}_{2} \mathrm{O}_{2}$ on SOD expression in LECs, showed a similar pattern with increased SOD at $2 \mathrm{~h}$ followed by an inhibition at $24 \mathrm{~h}$. These results suggest that SOD is temporally regulated by PGF and ROS during luteolysis in cattle. The dose of $\mathrm{H}_{2} \mathrm{O}_{2}$ used in the present study to examine SOD1 protein and total SOD activity did not affect significantly the viability of LECs.

Previous in vivo studies in cows demonstrated that injection of a luteolytic dose of PGF induces a transient $(1-2 \mathrm{~h})$ increase in the partial pressure of oxygen $\left(\mathrm{pO}_{2}\right)$ in the ovarian venous blood [11]. In addition, it has been shown that a functional PGF receptor (FPr) is present in bovine LECs, and that PGF acutely increased ROS production in these cells [6]. Moreover, the rat CL produces significant amounts of ROS [24] and increases ROS $\left(\mathrm{H}_{2} \mathrm{O}_{2}\right)$ generating capacity within a few hours after injection of a luteolytic dose of PGF $[8,9]$. In the present study, PGF stimulated the expressions of SOD1 mRNA, protein, and total SOD activity at $2 \mathrm{~h}$ in bovine CL tissue and LECs. The temporal pattern of SOD expression suggests a role for ROS and SOD during the beginning functional luteolysis in cows. On the other hand, SOD acts as an antioxidant enzyme, and together with catalase, protects the endothelium of a variety of tissues against ROS [25]. Taken together, SOD and ROS seem to be involved in the luteolytic cascade induced by PGF in bovine CL.

ROS have been implicated in luteolysis due to their ability to increase uterine PGF [10], to decrease $\mathrm{P}_{4}$ biosynthesis [15] and to induce apoptosis in LSCs [26]. The intraluteal production of ROS is regulated by SOD [15]. SOD catalyzes the dismutation of superoxide into oxygen and $\mathrm{H}_{2} \mathrm{O}_{2}$ [12]. SOD1 inhibition increases the steady-state levels of superoxide [27]. On the other hand, the presence of superoxide anions can induce intracellular SOD1. In the present study, $\mathrm{H}_{2} \mathrm{O}_{2}$ stimulated the expressions and activity of SOD1 at $2 \mathrm{~h}$ in bovine LECs. Sander et al. demonstrated an increase
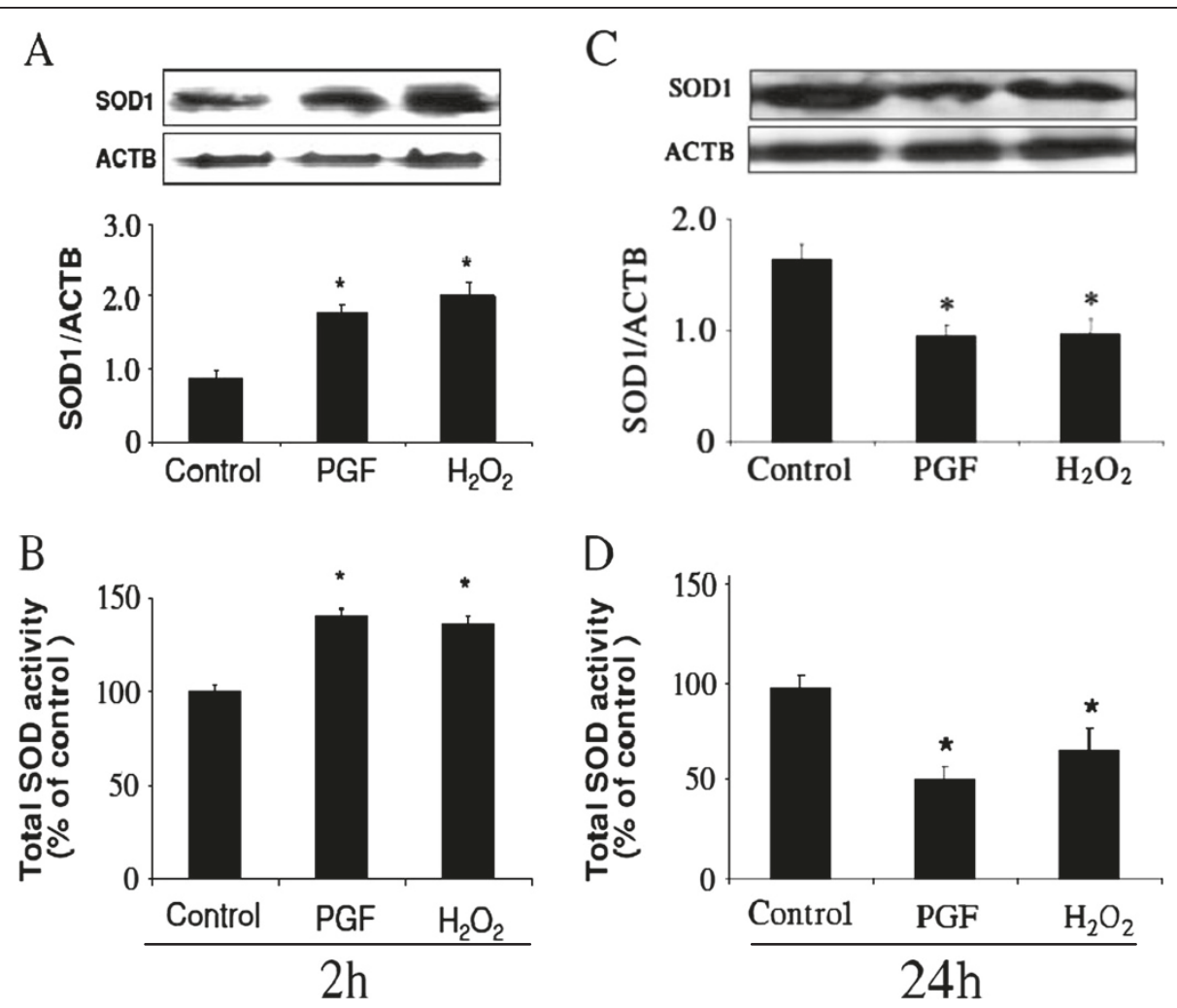

Figure 3 SOD1 protein expression and total SOD activity in LECs. Effects of PGF and $\mathrm{H}_{2} \mathrm{O}_{2}$ on the expression of SOD1 protein (Figure 3A, 3C) and total SOD activity (Figure 3B, 3D) in cultured bovine LECs. The cells were cultured with $1 \mu \mathrm{M} \mathrm{PGF}$ and $10 \mu \mathrm{M} \mathrm{H} \mathrm{H}_{2}$ for 2 and $24 \mathrm{~h}$. Photographs showed the expression of SOD1 protein $(23 \mathrm{kDa})$ and ACTB (42 kDa). The amount of SOD1 protein is expressed relative to the amount of ACTB. Total SOD activity was determined by a colorimetric method using SOD Assay kit-WST. Asterisks indicate significant differences between untreated cells and treated cells $(P<0.05)$. All values represent mean \pm SEM of four separate experiments. 


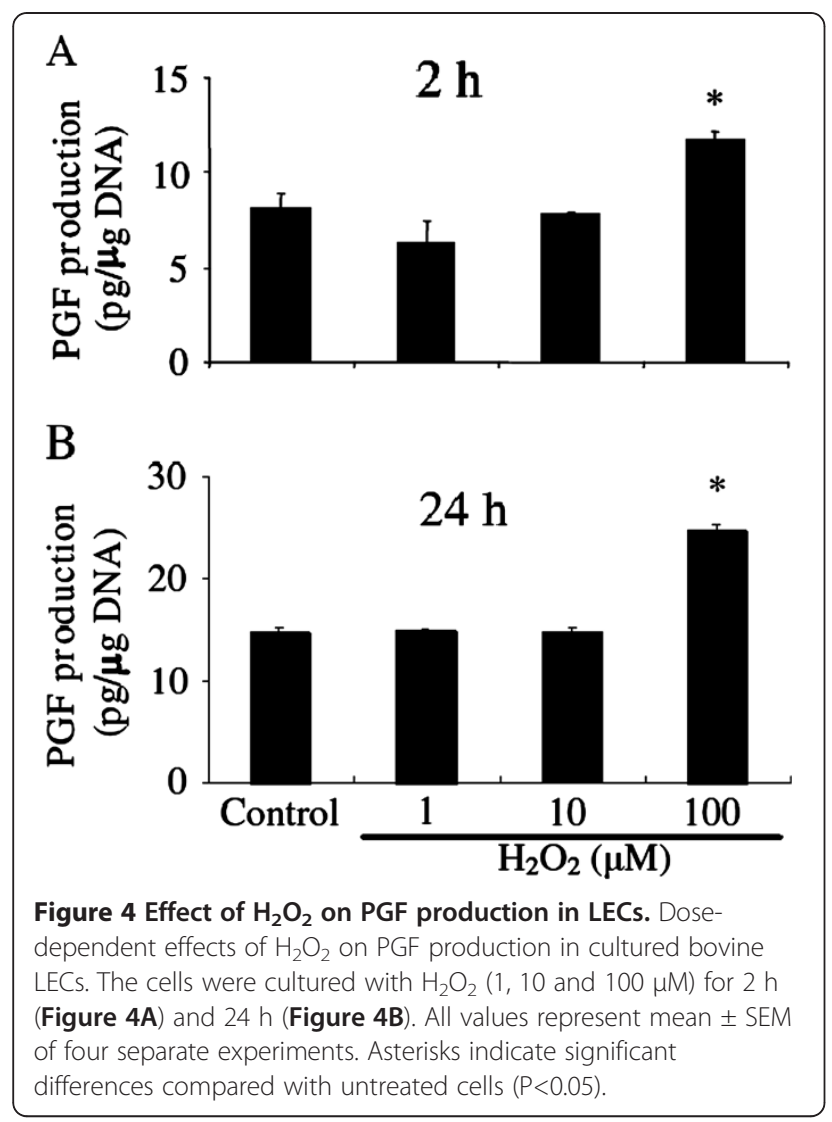

in total SOD activity and a decrease in catalase activity during $\mathrm{CL}$ regression in mice [28]. Since $\mathrm{H}_{2} \mathrm{O}_{2}$ has the capacity to increase PGF production in bovine LSCs [29] and LECs (the present study), as well as to induce apoptosis in bovine LSCs and human umbilical vein endothelial cells [29,30], increased levels of $\mathrm{H}_{2} \mathrm{O}_{2}$ may be crucial for luteal regression. The above findings also suggest that a local increase of ROS within the bovine CL facilitates the local production of PGF. Moreover, the concomitant increase of SOD and ROS may be due to the strong stimulatory effect of ROS on SOD in response to the increasing levels of PGF within the CL.

Although luteolytic PGF is derived from the uterus in many species, including ewes [31] and cows [2], a considerable amount of PGF is also synthesized by the CL [32] and LECs represent an important source of PGF [18]. Previous studies have reported that PGF increases the production of ROS in rats $[9,24]$ and cow in vivo [11]. Interestingly, ROS has been demonstrated to stimulate PGF production in the CL of rats [33], cows [29] and human [10]. In the present study, $\mathrm{H}_{2} \mathrm{O}_{2}$ stimulated PGF production in cultured bovine LECs. The above results suggest the presence of a positive feedback loop between PGF and ROS in the bovine CL during luteolysis. Also, the increase of intraluteal PGF induced by ROS seems to be crucial for promotion of luteal regression in cow.

The present study demonstrates that PGF and $\mathrm{H}_{2} \mathrm{O}_{2}$ inhibited the expression of SOD1 protein in bovine LECs cultured for $24 \mathrm{~h}$. The inhibitory effects of PGF and $\mathrm{H}_{2} \mathrm{O}_{2}$ on SOD expression at $24 \mathrm{~h}$ contrasted with their stimulatory effects at $2 \mathrm{~h}$. The increase in SOD observed at $2 \mathrm{~h}$ seems to be the result of an acute stimulatory effect of PGF on ROS production by LECs. However, the mechanism by which PGF and $\mathrm{H}_{2} \mathrm{O}_{2}$ inhibit the expression of SOD1 at $24 \mathrm{~h}$ of incubation is unclear. SOD catalyzes the dismutation of superoxide into $\mathrm{H}_{2} \mathrm{O}_{2}$ and oxygen, to maintain low-state levels of superoxide [12]. Therefore, a reduction of SOD by PGF and $\mathrm{H}_{2} \mathrm{O}_{2}$ at $24 \mathrm{~h}$ may enhance intraluteal ROS or superoxide radical accumulation for the promotion of structural luteolysis [29,30]. In support of such an idea, an accumulation of superoxide radicals and a decrease in SOD levels are associated with the inhibition of luteal $\mathrm{P}_{4}$ secretion [7] and apoptotic cell death [34].

Furthermore, SOD1 protein was localized in LECs (Additional file 1: Figure S1) and other types of luteal cells (Additional file 2: Figure S2). A robust SOD1 protein expression was detected in bovine $\mathrm{CL}$ tissue after PGF treatment (Additional file 2: Figure S2). These findings suggest that not only SOD1 in LECs but also in other types of luteal cells including LSCs are regulated during PGF induced luteolysis. Further studies are needed to clarify the relative contribution of LSCs in total luteal SOD during luteolysis in cow.

\section{Conclusions}

SOD is regulated by PGF and ROS in bovine LECs. SOD may play roles in controlling intraluteal PGF and ROS action during functional and structural luteolysis in cows.

\section{Additional files}

Additional file 1: Figure S1. Immunohistochemical examination of SOD1 in bovine luteal tissue. For localization of SOD1, bovine corpus luteum tissues was fixed with $10 \%$ phosphate buffer formalin, embedded with paraffin and cut into 4 micrometers of thickness. For antigen retrieval, sections were incubated in Tris-EDTA buffer ( $\mathrm{pH}$ 9.0) for 15 min at $98^{\circ} \mathrm{C}$. Normal horse serum blocking solution was used for inhibition of nonspecific bindings. The slides were then incubated with or without (negative control) SOD1 antibody raised in goat (Santa Cruz; sc-8637) at a dilution rate of 1/200. After washing, sections were incubated with biotinylated rabit anti goat lgG serum as the second antibody (1/4000). Horseradish peroxidase (HRP)-conjugated ABC (Vector Laboratory Inc., Burlingame, CA, USA) was applied to the section at room temperature for $30 \mathrm{~min}$. The binding sites were visualized using $0.02 \%$ 3,3diaminobenzidine tetrahydrochloride (DAB) in $50 \mathrm{mM}$ Tris- $\mathrm{HCl}(\mathrm{pH} 7.4)$ containing $0.02 \% \mathrm{H}_{2} \mathrm{O}_{2}$. After immunohistochemical staining, the sections were lightly counterstained with Mayer's hematoxylin. The sections were washed in distilled water, dehydrated in a graded series of ethanol, and cleared in xylene, coverslipped and observed under light field microscope. Immunohistochemical representative pictures of SOD1 were shown. Picture A showed the negative control (magnification: 200x). Picture B (magnification: 
200x) and C (magnification: 400x) showed the localization of SOD1 (brown color) in the cytoplasm of luteal endothelial cells. Red arrows indicated cells with strong signal while black arrows indicated cells with weak signal.

Additional file 2: Figure S2. Immunohistochemistry of SOD1 in bovine luteal tissue after PGF injection. The method for detection of SOD1 in bovine $\mathrm{CL}$ tissue after PGF injection was similar to that described above in the "Additional file 1: Figure S1" section. Immunohistochemical representative pictures of SOD1 were shown. Picture A was positive staining while picture B was negative control. SOD1 protein expression (brown color) in cytoplasm of luteal cells was robust after PGF-injection. Bar $=50 \mu \mathrm{m}$.

\section{Competing interests}

The authors declare that they have no competing interests.

\section{Authors' contributions}

HW participated in the in vitro experiments and drafted the manuscript. TJA conceived of the study, participated in its design and performed in vivo and in vitro experiments. He also helped to draft the manuscript. ShY participated in data analysis and drafted the manuscript. HA carried out the in vitro experiments. $\mathrm{KO}$ participated in experimental design and discussion. All authors read and approved the final manuscript

\section{Acknowledgements}

This research has been supported by a Grant-in-Aid for Scientific Research (No.225803188) of the Japan Society for the Promotion of Science (JSPS). The authors thank Dr. DJ Skarzynski and Dr. MM Bah for the preparation of animals and for the assistance in $\mathrm{CL}$ collection.

HW was supported by JSPS/Ronpaku dissertation program (No: VNM-11011).

Received: 9 June 2012 Accepted: 22 October 2012

Published: 26 October 2012

\section{References}

1. Auletta FJ, Flint AP: Mechanisms controlling corpus luteum function in sheep, cows, nonhuman primates, and women especially in relation to the time of luteolysis. Endocr Rev 1988, 9:88-105.

2. McCracken JA, Custer EE, Lamsa JC: Luteolysis: a neuroendocrinemediated event. Physiol Rev 1999, 79:263-323.

3. Okuda K, Uenoyama Y, Lee KW, Sakumoto R, Skarzynski DJ: Progesterone stimulation by prostaglandin F2alpha involves the protein kinase $C$ pathway in cultured bovine luteal cells. J Reprod Dev 1998, 44:79-84

4. Pate $\mathrm{JL}$, Condon WA: Regulation of steroidogenesis and cholesterol synthesis by prostaglandin F-2alpha and lipoproteins in bovine luteal cells. J Reprod Fertil 1989, 87:439-446.

5. Meidan R, Levy N, Kisliouk T, Podlovny L, Rusiansky M, Klipper E: The yin and yang of corpus luteum-derived endothelial cells: balancing life and death. Domest Anim Endocrinol 2005, 29:318-328.

6. Lee SH, Acosta TJ, Yoshioka S, Okuda K: Prostaglandin F2alpha regulates the nitric oxide generating system in bovine luteal endothelial cells. J Reprod Dev 2009, 55:418-424.

7. Kato H, Sugino N, Takiguchi S, Kashida S, Nakamura Y: Roles of reactive oxygen species in the regulation of luteal function. Rev Reprod 1997, 2:81-83.

8. Sawada M, Carlson JC: Rapid plasma membrane changes in superoxide radical formation, fluidity, and phospholipase A2 activity in the corpus luteum of the rat during induction of luteolysis. Endocrinology 1991, 128:2992-2998,

9. Tanaka M, Miyazaki T, Tanigaki S, Kasai K, Minegishi K, Miyakoshi K, Ishimoto $\mathrm{H}$, Yoshimura Y: Participation of reactive oxygen species in PGF2alphainduced apoptosis in rat luteal cells. J Reprod Fertil 2000, 120:239-245.

10. Sugino N, Karube-Harada A, Kashida S, Takiguchi S, Kato H: Reactive oxygen species stimulate prostaglandin F2alpha production in human endometrial stromal cells in vitro. Hum Reprod 2001, 16:1797-1801.

11. Acosta TJ, Bah MB, Korzekwa A, Woclawek-Potocka I, Markiewicz W, Jaroszewski $\mathrm{JJ}$, Okuda K, Skarzynski DJ: Acute changes in circulating concentrations of progesterone and nitric oxide and partial pressure of oxygen during prostaglandin F2alpha-induced luteolysis in cattle. J Reprod Dev 2009, 55:149-155.

12. Fridovich I: Superoxide radical and superoxide dismutases. Annu Rev Biochem 1995, 64:97-112

13. Fridovich I: The biology of oxygen radicals. Science 1978, 201:875-880.
14. Sugino N, Nakamura Y, Takeda O, Ishimatsu M, Kato H: Changes in activities of superoxide dismutase and lipid peroxide in corpus luteum during pregnancy in rats. J Reprod Fertil 1993, 97:347-351.

15. Sugino N, Takiguchi S, Kashida S, Takayama H, Yamagata Y, Nakamura Y, Kato H: Suppression of intracellular superoxide dismutase activity by antisense oligonucleotides causes inhibition of progesterone production by rat luteal cells. Biol Reprod 1999, 61:1133-1138.

16. Miyamoto Y, Skarzynski DJ, Okuda K: Is tumor necrosis factor alpha a trigger for the initiation of endometrial prostaglandin F2alpha release at luteolysis in cattle? Biol Reprod 2000, 62:1109-1115.

17. Klipper E, Gilboa T, Levy N, Kisliouk T, Spanel-Borowski K, Meidan R: Characterization of endothelin-1 and nitric oxide generating systems in corpus luteum-derived endothelial cells. Reproduction 2004, 128:463-473.

18. Acosta TJ, Yoshioka S, Komiyama J, Lee SH, Grazul-Bilska AT, Skarzynski DJ, Okuda $K:$ Effects of storage and passage of bovine luteal endothelial cells on endothelin-1 and prostaglandin F2alpha production. J Reprod Dev 2007, 53:473-480.

19. Lee $\mathrm{S}$, Acosta TJ, Nakagawa Y, Okuda K: Role of nitric oxide in the regulation of superoxide dismutase and prostaglandin F2alpha production in bovine luteal endothelial cells. J Reprod Dev 2010, 56:454-459.

20. Wong $\mathrm{H}$, Anderson WD, Cheng T, Riabowol KT: Monitoring mRNA expression by polymerase chain reaction: the "primer-dropping" method. Anal Biochem 1994, 223:251-258.

21. Okuda K, Kasahara Y, Murakami S, Takahashi H, Woclawek-Potocka I, Skarzynski DJ: Interferon-tau blocks the stimulatory effect of tumor necrosis factor-alpha on prostaglandin F2alpha synthesis by bovine endometrial stromal cells. Biol Reprod 2004, 70:191-197.

22. Osnes T, Sandstad O, Skar V, Osnes M, Kierulf P: Total protein in common duct bile measured by acetonitrile precipitation and a micro bicinchoninic acid (BCA) method. Scand I Clin Lab Invest 1993, 53:757-763.

23. Labarca C, Paigen K: A simple, rapid, and sensitive DNA assay procedure. Anal Biochem 1980, 102:344-352.

24. Riley JC, Behrman HR: In vivo generation of hydrogen peroxide in the rat corpus luteum during luteolysis. Endocrinology 1991, 128:1749-1753.

25. Muzykantov VR: Targeting of superoxide dismutase and catalase to vascular endothelium. J Control Release 2001, 71:1-21.

26. Korzekwa AJ, Okuda K, Woclawek-Potocka I, Murakami S, Skarzynski DJ: Nitric oxide induces apoptosis in bovine luteal cells. J Reprod Dev 2006, 52:353-361.

27. Juarez JC, Manuia M, Burnett ME, Betancourt O, Boivin B, Shaw DE, Tonks NK, Mazar AP, Donate F: Superoxide dismutase 1 (SOD1) is essential for $\mathrm{H} 2 \mathrm{O} 2$-mediated oxidation and inactivation of phosphatases in growth factor signaling. Proc Natl Acad Sci U S A 2008, 105:7147-7152.

28. Sander VA, Piehl L, Facorro GB, Rubin de Celis E, Motta AB: Regulation of functional and regressing stages of corpus luteum development in mice. Role of reactive oxygen species. Reprod Fertil Dev 2008, 20:706-769.

29. Nakamura T, Sakamoto K: Reactive oxygen species up-regulates cyclooxygenase-2, p53, and Bax mRNA expression in bovine luteal cells. Biochem Biophys Res Commun 2001, 284:203-210.

30. Suhara T, Fukuo K, Sugimoto T, Morimoto S, Nakahashi T, Hata S, Shimizu M, Ogihara T: Hydrogen peroxide induces up-regulation of Fas in human endothelial cells. J Immunol 1998, 160:4042-4047.

31. Raw RE, Silvia WJ: Activity of phospholipase $\mathrm{C}$ and release of prostaglandin $\mathrm{F} 2$ alpha by endometrial tissue from ovariectomized ewes receiving progesterone and estradiol. Biol Reprod 1991, 44:404-412.

32. Lee J, McCracken JA, Stanley JA, Nithy TK, Banu SK, Arosh JA: Intraluteal Prostaglandin Biosynthesis and Signaling Are Selectively Directed Towards PGF2alpha During Luteolysis but Towards PGE2 During the Establishment of Pregnancy in Sheep. Biol Reprod 2012, 87:97.

33. Wu XM, Sawada M, Carlson JC: Stimulation of phospholipase A2 by xanthine oxidase in the rat corpus luteum. Biol Reprod 1992, 47:1053-1058.

34. Buttke TM, Sandstrom PA: Oxidative stress as a mediator of apoptosis. Immunol Today 1994, 15:7-10.

\section{doi:10.1186/1477-7827-10-87}

Cite this article as: Vu et al:: Roles of prostaglandin F2alpha and hydrogen peroxide in the regulation of Copper/Zinc superoxide dismutase in bovine corpus luteum and luteal endothelial cells. Reproductive Biology and Endocrinology 2012 10:87. 